\section{Nitrogen removal and its determinants in hybrid Populus clones for bioenergy plantations after two biennial rotations in two temperate sites in northern Italy}

\author{
Pierluigi Paris ${ }^{(1)}$, Leonardo Mareschi ${ }^{(2)}$, Maurizio Sabatti ${ }^{(3)}$, \\ Luca Tosi $^{(1-3)}$, Giuseppe Scarascia-Mugnozza ${ }^{(3)}$
}

The sustainability of bioenergy coppice plantations is strongly affected by the Nitrogen $(\mathrm{N})$ balance, whose removal is very high due to the frequent harvest of large quantities of biomass composed of small-sized shoots. Poplar bioenergy coppice plantations could have a Nitrogen removal comparable to herbaceous crops. In this study, five hybrid poplar genotypes ("AF2", "AF6", "Monviso", "83.148.041", "1214") were compared for tree morphological traits related to yield, $\mathrm{N}$ removal in the harvested biomass and Nitrogen wood concentration $(\mathrm{N}$ $\%)$ after two biennial coppice rotations in two experimental plantations located in northern Italy. $\mathrm{N}$ removal was primarily influenced by biomass production, and linear positive relationships between biomass yield and $\mathrm{N}$ removal were established. $\mathrm{N}$ removal also varied greatly among genotypes due to clonal differences in yield and in $\mathrm{N} \%$, in relation to significant differences among clones for their branching and sprouting habits. In the first rotation, branchiness was positively correlated to $\mathrm{N} \%$ with a significant coefficient of determination $\left(R^{2}=0.813\right)$, while at the end of the second rotation it was also significantly correlated to the shoots per stool ratio $\left(\mathrm{R}^{2}=0.804\right)$. "Monviso" and "83.148.041" were the clones showing the highest yield, but also a high $\mathrm{N} \%$ associated to an high level of branchiness and shoots per stool ratio. Our results highlight that poplar genotype selection for sustainable $\mathrm{N}$ management should be aimed at genotypes with low wood $\mathrm{N}$ concentration, coupling high yield with low branching and sprouting habits as in the case of the clone "AF2".

Keywords: Branching Habit, Coppice Plantations, Fertilization, Growth Traits, Sprouting Habit

\section{Introduction}

Tree bioenergy plantations have the potential to produce large quantities of biomass to partially replace fossil fuels, as well as to mitigate the global warming (Chum et al. 2011), provided that they are environmentally and socially sustainable. Compared to herbaceous energy crops, tree bioenergy plantations may be more sustainable for biofuel conversion in terms of energy and $\mathrm{CO}_{2}$ balance (Blanco-Canqui 2010, Scharlemann \& Laurance 2008). In many temperate countries, bioenergy coppice plantations of fast growing trees have been established with a short harvesting period of 2-3 years (Christersson \& Verma 2006, El Kasmioui \& Ceulemans 2012). Such plantations are frequently referred to as short rotation coppices (SRCs). Tree species most frequently used for temperate SRCs include hybrids of wil-

(1) C.N.R.- Istituto di Biologia Agroambientale e Forestale, v. G. Marconi 2, I-05010 Porano (TR - Italy); (2) Corpo Forestale dello Stato, v. A. Pacinotti 5, I-01100, Viterbo (Italy); (3) Di.B.A.F.- Università degli Studi della Tuscia, v. S. Camillo de Lellis, I-01100 Viterbo (Italy)

(a) Pierluigi Paris (piero.paris@ibaf.cnr.it)

Received: Jan 28, 2014 - Accepted: Oct 30, 2014

Citation: Paris P, Mareschi L, Sabatti M, Tosi L, Scarascia-Mugnozza G, 2015. Nitrogen removal and its determinants in hybrid Populus clones for bioenergy plantations after two biennial rotations in two temperate sites in northern Italy. iForest 8: 668-676 [online 201502-02] URL: http://www.sisef.it/iforest/contents/?id=ifor1254-007

Communicated by: Gianfranco Minotta

lows (Salix spp.), poplars (Populus spp), eucalyptus (Eucalyptus spp.) and robinia species (Robinia pseudoacacia L.). The use of clones of such species with improved yield traits is very common.

SRC plantations are most frequently established on agricultural arable soils, and their cultivation cycle is fully mechanized, from establishing trees to harvesting the biomass. Despite this high level of mechanization, their energy balance is generally very positive (Djomo et al. 2011, Manzone et al. 2009), with more than $60 \%$ of the crop energy balance represented by nitrogen $(\mathrm{N})$ fertilization.

The importance of $\mathrm{N}$ fertilization depends on two main factors. Firstly, similar to other plant nutrient elements, $\mathrm{N}$ is largely removed with the frequent and complete cyclical harvest of the aboveground biomass. Nutrient removal in SRCs is far greater than in conventional forestry (Lars 2002, Hansen et al. 1988, Van Miegroet et al. 1994), due to the high density of the shoot population, characterized by very small sized stems and a high bark volume (wood/bark ratio - Klasnja et al. 2002, Adler et al. 2005, Guidi et al. 2009). Secondly, the chemical synthesis of $N$ fertilizers is an industrial process requiring an enormous quantity of energy (Kaltschmitt \& Reinhardt 1997).

A third element highlighting the importance of nitrogen fertilization for bioenergy sustainability lies in its environmental impact (Erisman et al. 2010, Heller et al. 2003), in terms of groundwater pollution by nitrate leaching and ozone depletion by the emission of nitrous oxides after the combustion of biomass with a relative high $\mathrm{N}$ concentration. Low requirements of $\mathrm{N}$ fertilizer and high efficiency of $\mathrm{N}$ utilization are therefore desirable crop traits, especially for energy crops. This is relevant to achieve a favorable, positive energy balance for the SRC crops (Scholz \& Ellerbrock 2002).

Nevertheless, little is known about the nutrient use and efficiency of poplar SRCs, and how they vary according to factors such as site conditions, biomass yield and genetic origin of the planting material. Significant variations in $\mathrm{N}$ uptake and $\mathrm{N}$ use efficiency (NUE) have been found among clones of important fast-growing tree species such as poplars (Berthelot et al. 2000, Heilman \& Stettler 1986), willows (Adegbidi et al. 2001), and eucalypts (Safou-Matondo et al. 2005). According to Vitousek (1982), NUE indicates the net primary productivity (NPP) to total $\mathrm{N}$ uptake in a certain period. However, studying $\mathrm{N}$ balance in fast growing tree plantations, the aforementioned authors calculated NUE as the ratio between the harvested biomass over its $\mathrm{N}$ content, concluding that NUE is an important factor for the selection of planting material for SRCs. No 
Tab. 1 - Main characteristics of the Vinovo and Bigarello study sites with experimental plots of hybrid poplar clones under short rotation coppicing management in northern Italy. (a): Köppen \& Greiger classification (Kottek et al. 2006)

\begin{tabular}{|c|c|c|}
\hline Characteristics & Vinovo & Bigarello \\
\hline Long/Lat & $\begin{array}{l}7^{\circ} 38^{\prime} 20.40^{\prime \prime} \mathrm{E} \\
44^{\circ} 57^{\prime} 25.03^{\prime \prime} \mathrm{N}\end{array}$ & $\begin{array}{l}10^{\circ} 53^{\prime} 11^{\prime \prime} \mathrm{E} \\
45^{\circ} 11^{\prime} 26.93^{\prime \prime} \mathrm{N}\end{array}$ \\
\hline Climate $^{\mathrm{a}}$ & $\begin{array}{l}\text { Cfb (Warm temperate, fully humid } \\
\text { with warm summer) }\end{array}$ & $\begin{array}{l}\text { Cfa (Warm temperate, fully humid } \\
\text { with hot summer) }\end{array}$ \\
\hline $\begin{array}{l}\text { May to August } \\
\text { Prec. }(\mathrm{mm})\end{array}$ & $\begin{array}{l}60 \mathrm{~mm} \text { in } 2003 ; 143 \mathrm{~mm} \text { in } 2004 ; \\
233 \text { in } 2005 ; 198 \text { in } 2006\end{array}$ & $\begin{array}{l}67 \mathrm{~mm} \text { in } 2003 ; 216 \mathrm{~mm} \text { in } 2004 ; \\
292 \text { in } 2005 ; 181 \text { in } 2006\end{array}$ \\
\hline $\begin{array}{l}\text { Soil } \\
(0-20 \mathrm{~cm} \text { depth })\end{array}$ & $\begin{array}{l}\text { (14.4\% clay, } 19.9 \% \text { sand); } \mathrm{pH}_{\text {water }} \\
7 ; \text { tot } \mathrm{N} \text { soluble } 10.1 \mathrm{mg} \mathrm{N} \mathrm{kg}\end{array}$ & $\begin{array}{l}\text { (43.3\% clay, } 16.8 \% \text { sand }) ; \mathrm{pH}_{\text {water }} \\
8.34 \text {; tot } \mathrm{N} \text { soluble } 10.6 \mathrm{mg} \mathrm{N} \mathrm{kg}\end{array}$ \\
\hline $\begin{array}{l}\text { Cultivation } \\
\text { model }\end{array}$ & $\begin{array}{l}\text { Planting date: April 2003; plan- } \\
\text { ting density } 5900 \text { cuttings ha }{ }^{-1} \text {; bi- } \\
\text { ennial harvestings in Jan. } 2005 \\
\text { and Dec. } 2006 \text {; No fertilization }\end{array}$ & $\begin{array}{l}\text { Planting date: March-April 2003; } \\
\text { planting density } 5900 \text { cuttings } \\
\text { ha }^{-1} \text {; biennial harvestings in Dec. } \\
2004 \text { and Jan. } 2007 \text {; No fertilization }\end{array}$ \\
\hline
\end{tabular}

attempts were made to connect the NUE of clones with clonal biomass yield characteristics, such as the distribution among stem shoot populations with different dimensions, the allocation ratio between branch and stem woody biomass, the shoot density or the number of shoots on the stools. Indeed, all these parameters may vary significantly among poplar clones. Such variability could affect N removal and NUE at a clonal level in poplar hybrids, altering the percentage of bark and young woody tissues in the total harvested woody biomass (Paris et al. 2006) This resulted from a high absorption of $\mathrm{N}$, along with many other plant nutrients, by poplar trees, resulting in a higher $\mathrm{N}$ concentration in the bark than wood (Laureysens et al. 2004), and the percentage of bark to the total aboveground woody biomass strongly increases with decreasing stem dimensions (Guidi et al. 2009, Klasnja et al. 2002) and increasing branchiness (Paris et al. 2006).

The objective of this work was to examine the effects of coppicing cycles and hybrid poplar clones on stool morphology yield traits, wood $\mathrm{N}$ concentration (N\%), NUE and $\mathrm{N}$ removal, with the aim of assessing clone suitability for bioenergy production and helping to refine the criteria of $\mathrm{N}$ fertilization for the woody crop in temperate plantation forestry.

In 2003, a network of three experimental plantations on arable soils was established in

Tab. 2 - List of hybrid poplar clones studied in northern Italy. (a): denotes where and by whom the crosses were made; $(\mathrm{M})$ male; $(\mathrm{F})$ female; $(\mathrm{Yr})$ : year of cross.

\begin{tabular}{lclccc}
\hline Genotype & Sex & Parentage & Yr & Breeder $^{\text {a }}$ & $\begin{array}{c}\text { Selection } \\
\text { for }\end{array}$ \\
\hline AF2 & M & $P . \times$ canadensis & 1992 & F. Alasia, Savigliano (Italy) & biomass \\
AF6 & F & $(P . \times$ generosa $) \times P$. nigra & 1993 & F. Alasia, Savigliano (Italy) & biomass \\
Monviso & F & $(P . \times$ generosa $) \times P$. nigra & 1991 & F. Alasia, Savigliano (Italy) & biomass \\
83.148 .041 & M & $P . \times$ canadensis & 1983 & CRA-PLF, Casale M. (Italy) & biomass \\
I-214 & F & $P . \times$ canadensis & 1929 & G. Jacometti, Villafranca P. & plywood \\
& & & & (Italy) & \\
\hline
\end{tabular}

tablishment and cultural practices, as reported in Tab. 1. The list of poplar clones compared in this study is reported in Tab. 2. Clone I-214 is a traditional selection developed in Italy for timber production. The other clones are new cultivars recently developed in Italy, specifically for biomass production under SRC management. These clones are currently under evaluation in Italy, as well in other European countries with various site conditions, such as Spain (Sixto et al. 2010) and Romania (Filat et al. 2010).

The experimental design consisted in a randomized block with three-four replications per clone. Each replication was made up of homogenous plots with 60 trees organized in 5 rows (inter-row distance $280 \mathrm{~cm}$ ), each with 12 trees (intra-row spacing $60 \mathrm{~cm}$ ), with an inner sampling area of one row with 12 trees $\left(20.16 \mathrm{~m}^{2}\right)$.

No fertilization was supplied at any point along the cultural cycle of plantations, either before planting or during cultivation. Biomass harvesting, in biennial cycles, was performed mechanically in winter after leaf shedding.

\section{Field sampling}

Sampling and measurements were carried out at both plantations soon before mechanical harvesting in winter 2004/2005 and $2006 / 2007$, at the end of the first and second biennial rotation cycle, respectively. Measurements were aimed at determining the main growth traits of the clones, i.e., stem dimensions and the number of shoots per stool. More details on the sampling procedures adopted and the allometric regression equations used are reported by Paris et al. (2011).

The field sampling for nitrogen content was organized as follows. In each experimental site, the diameter at $100 \mathrm{~cm}$ above the ground (D) of all individual shoots was measured, and the shoot population of each clone recorded into diameter classes (diametric classes $1 \mathrm{~cm}$ wide; the numeric value of each class represented the central value, i.e., class 1 included all sections whose diameter ranged from 0.5 to $1.5 \mathrm{~cm}$ ). Thereafter, 10 $\mathrm{cm}$ thick stem discs were obtained from 1015 undamaged sample shoots (stem and branches with no evident damages such as wounds, pest and disease attacks) per each clone. The sampled shoots were randomly selected so that the diameter range in each experimental site and clone was well representing the whole variation across sites and clones.

For each sample shoot, D and total height (H) were recorded with a caliper (precision $0.1 \mathrm{~mm}$ ) and tape (precision $0.1 \mathrm{~cm}$ ), respectively, and the fresh weight of both stem and branches was directly measured in the field with an electronic portable hanging scale (HBC 20K 50, KERN, Germany - precision 
$50 \mathrm{~g})$.

The stem discs were collected at three different heights above the ground (Fig. 1) measured with a tape (precision $0.1 \mathrm{~cm}$ ): (i) $20 \mathrm{~cm}$ (disc D20, with $R$ radius); (ii) at half of the total stem height (disc $\mathrm{H} / 2$ ); (iii) and at the height where the stem diameter was 2 $\mathrm{cm}$ (disc D2, with $r$ radius). These discs represent 3 stem sections of the sample shoot: (i) the basal section, with a cylindrical shape and volume $V_{\text {cy }}$; (ii) the intermediate section $(\mathrm{H} / 2)$, whose volume $\left(V_{\mathrm{f}}\right)$ can be estimated as a frustum of cone; (iii) the top section (D2) with a conic shape and volume $V_{\mathrm{c}}$. Branches were sampled separately for each sample shoot, collecting 3 discs from their basal, median and apical part. Three average branches per shoot were selected along its entire height. Disc samples represented approx. $5 \%$ of the total weight of each individual sample shoot.

Percentage branchiness (branch \%) of each sample shoot was calculated as the branch weight to total shoot weight ratio.

Immediately after sampling, the radius of each disc was recorded by cross-measurement with a digital caliper (precision 0.1 $\mathrm{mm}$ ). Each disc was then placed into a plastic bag for minimizing moisture loss.

\section{Laboratory procedures and nitrogen analysis}

One week after field collection, sample disc volume over bark was estimated by the water displacement method, thereby obtaining individual density estimates. Each disc was then split into two equal parts, one used for dry weight determinations (at $105{ }^{\circ} \mathrm{C}$, to constant weight), and the other for $\mathrm{N}$ determinations.

Discs for $\mathrm{N}$ determinations were dried at $40{ }^{\circ} \mathrm{C}$ to constant weight, and then ground by a laboratory mill (M10 Basic Microfine Grinder, IKA, Staufen, Germany), obtaining a homogeneous dust which was dried again overnight at $40{ }^{\circ} \mathrm{C}$, and subsequently analyzed by CHN gas chromatography (Carlo Erba NA 1500, Italy) to determine the relative percentage $\mathrm{N}$ concentration $(\mathrm{N} \%)$.

Stem volume over bark was estimated for each sample shoot by summing the volumes of the 2 stem sections and the top section, using the formulas for the basal cylinder $\left(V_{\mathrm{cy}}\right.$ $\left.=\pi r^{2} h_{1}\right)$, for the intermediate frustum of a cone $\left(V_{\mathrm{f}}=1 / 3 \pi h_{2}\left[R^{2}+R r+r^{2}\right]\right)$, and for the top cone $\left(V_{\mathrm{c}}=\left[\begin{array}{ll}\pi h_{3} & r^{2}\end{array}\right] / 3\right)$, respectively, where $V$ is the volume, $h_{1-3}$ are the height of the three stem sections, $R$ the lower radius, and $r$ the upper radius (see also Fig. 1). Conversion of fresh stem volume to stem dry weight was done using the recorded density of each stem disc.

Regarding the $\mathrm{N}$ content of three 3 stem sections, $\mathrm{N}$ concentrations were averaged over the discs at the basal (D20), intermediate $(\mathrm{DH} / 2)$ and top (D2) sections, respective-

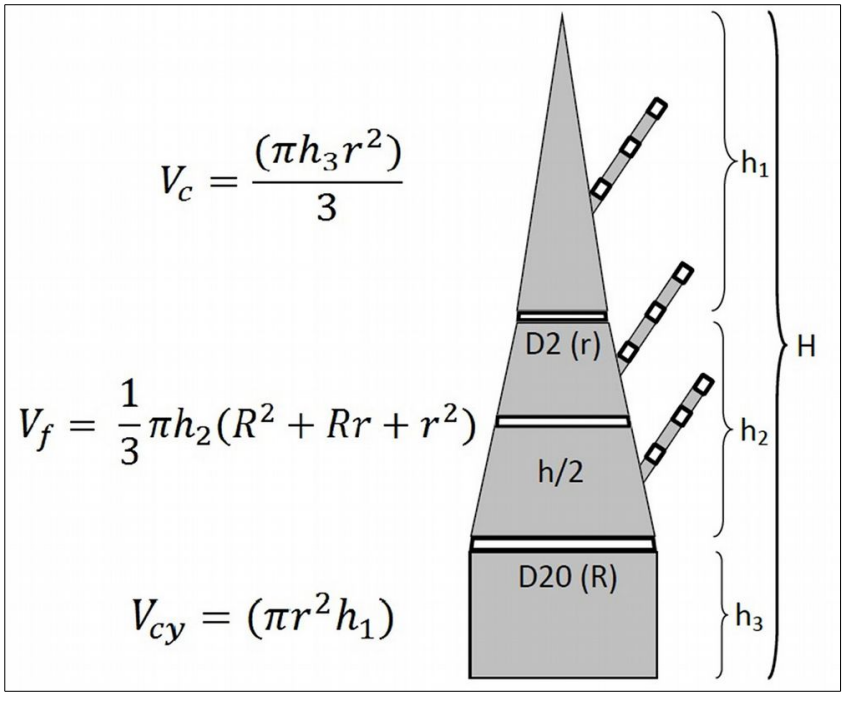

Fig. 1 - Schematic layout of wood discs sampled from the stem (D20; h/2, D2) and branches of sample shoots and the three main sections for the stem volumetric determination (basal, median and apical sections). $\left(V_{\mathrm{c}}\right)$ : volume of the apical cone; $\left(V_{\mathrm{f}}\right)$ : volume of the intermediate frustum of cone; $\left(V_{\text {cy }}\right)$ : volume of the basal cylinder; $\left(\mathrm{h}_{1}\right.$, $\mathrm{h}_{2}, \mathrm{~h}_{3}$ ): heights of the three stem sections considered; $(\mathrm{H})$ : total stem height; $(R)$ : lower radius; $(r)$ : upper radius.

ly. For the remaining branches, the branch $\mathrm{N}$ concentration was multiplied for the branch weight. The $\mathrm{N}$ content for each sample shoot was obtained by summing the $\mathrm{N}$ amounts of the three stem sections, including the branches wood nitrogen. The $\mathrm{N}$ uptake was then calculated per weight of each sample shoot according to its diameter class, and used for the estimation of total $\mathrm{N}$ uptake for each clone and site ( $\mathrm{N}$ uptake, $\left.\mathrm{kg} \mathrm{ha}^{-1}\right)$. NUE (kg $\mathrm{dm} \mathrm{kg} \mathrm{N}^{-1}$ ) was finally obtained dividing the above-ground woody biomass for each clone by its $\mathrm{N}$ uptake.

\section{Statistical analysis}

In each site, analysis of variance (ANOVA) was used to analyze the main effects of clone and cycle along with their interaction on growth parameters (D; H; Shoots/stool ratio; branch \%) and $\mathrm{N}$ use parameters (N\%; $\mathrm{N}$ uptake, NUE). This was carried out using a randomized complete block design with site, clone, cycle and clone $\times$ cycle as fixed factors and block as a random factor. Plot means for $\mathrm{D}, \mathrm{H}, \mathrm{N}$ shoots/stool ratio, $\mathrm{N} \%, \mathrm{~N}$ uptake and NUE were the units of replication. Individual branchiness of test shoots after angular transformation $(\alpha=\arcsin \sqrt{ } \%)$, was the unit of replication for branchiness. For significant ANOVA effects, post-hoc Duncan's test $(p \leq 0.05)$ was used to test for significant differences between treatment means. Pearson's correlation among growth and yield parameters (D; H; shoots/stool ratio; branch.\%; Yield) and the different $\mathrm{N}$ use parameters ( $\mathrm{N} \%$; $\mathrm{N}$ uptake) was also carried out. Average clonal values stratified per site, cycle and clone $(n=3-4)$ of the sampled parameters were used in this analysis. Finally, average plot values were used to analyze the relationship between Yield and $\mathrm{N}$ uptake, according to the two rotation cycles studied.

\section{Results}

\section{Growth parameters}

Results of the ANOVA carried out on growth parameters are shown in Tab. 3. At both sites, clone and cycle effects on stem or shoot dimensions (D and $\mathrm{H}$ ) were generally highly significant after ANOVA. Coppicing significantly decreased both stem dimensions ( $\mathrm{D}$ and $\mathrm{H})$ in the two sites, with a more evident effect on $\mathrm{D}$, which was reduced almost by half from the first to the second rotation at both sites (Tab. 4). Clone AF2 had consistently higher values in stem dimensions across the two rotation cycles, in both sites.

At both sites, clone and cycle effects on branchiness were generally highly significant. Coppicing strongly reduced plant branchiness in both sites, i.e, the first coppicing strongly decreased the amount of aboveground woody biomass allocated to branches. At both sites, clones "Monviso", "83. 148.041" and "I-214" (at Bigarello) had the highest values of branchiness after the first biennial rotation, while the clone "AF2" had the lowest values. After the second rotation, the clone effect on branchiness was not significant at Vinovo, while a significant clone $\times$ cycle interaction in Bigarello, with clones "AF2" and "83.148.041" having the lowest values of branchiness.

At both sites, the shoots/stool ratio was affected by the rotation cycle, strongly increasing from the first to the second rotation as a consequence of coppicing. After the first rotation, no significant differences among clones were found for this parameter at both sites. After the second rotation, the clone effect was very significant in Bigarello. Clones "Monviso" and "83.148.041" had the highest values of the shoots/stool ratio in both sites, while clone "AF2" had the lowest. 
Tab. 3 - ANOVA F and p-values for morphological growth traits and Nitrogen (N) status of shoots of hybrid poplar clones after two rotations in the study sites (northern Italy). (1): Total shoot height; (2): Shoot diameter, measured at $100 \mathrm{~cm}$ above the ground; (3): percentage allocation ratios between stem and branch woody biomass;. (4): number of shoots on the stool; (5): percentage concentration of $\mathrm{N}$ in the above ground woody biomass, including wood and bark; (6): N content in the harvestable above ground woody biomass; (7): Nitrogen Use Efficiency.

\begin{tabular}{|c|c|c|c|c|c|c|c|c|c|c|c|c|c|c|c|}
\hline \multirow{2}{*}{ Site } & \multirow{2}{*}{$\begin{array}{l}\text { Source of } \\
\text { variation }\end{array}$} & \multicolumn{2}{|r|}{$\mathbf{H}^{1}$} & \multicolumn{2}{|r|}{$\mathbf{D}^{2}$} & \multicolumn{2}{|c|}{ Branchiness $^{3}$} & \multicolumn{2}{|c|}{$\begin{array}{c}\text { Shoots/stool } \\
\text { Ratio }^{4}\end{array}$} & \multicolumn{2}{|c|}{$\mathrm{N} \%{ }^{5}$} & \multicolumn{2}{|c|}{ N Uptake ${ }^{6}$} & \multicolumn{2}{|c|}{$\mathbf{N U E}^{7}$} \\
\hline & & $\mathbf{F}$ & $\mathbf{p}$ & $\mathbf{F}$ & p & $\mathbf{F}$ & $\mathbf{p}$ & $\mathbf{F}$ & $\mathbf{p}$ & $\mathbf{F}$ & $\mathbf{p}$ & $\mathbf{F}$ & $\mathbf{p}$ & $\mathbf{F}$ & $\mathbf{p}$ \\
\hline \multirow[t]{3}{*}{ Vinovo } & Clone & 16.4 & $<0.0001$ & 5.3 & $<0.01$ & 4.6 & $<0.01$ & 0.6 & 0.696 & 313.2 & $<0.0001$ & 16.5 & $<0.0001$ & 208.3 & $<0.001$ \\
\hline & Cycle & 429 & $<0.0001$ & 396 & $<0.0001$ & 64.2 & $<0.0001$ & 360 & $<0.0001$ & 954.6 & $<0.0001$ & 34.4 & $<0.0001$ & 638.2 & $<0.001$ \\
\hline & Site $\times$ Clone & 1.1 & 0.383 & 0.7 & 0.596 & 0.8 & 0.512 & 1 & 0.414 & 107 & $<0.0001$ & 8.1 & $<0.01$ & 48.4 & $<0.0001$ \\
\hline \multirow[t]{3}{*}{ Bigarello } & Clone & 27 & $<0.0001$ & 6.8 & $<0.01$ & 6.1 & $<0.01$ & 6.9 & $<0.01$ & 45.8 & $<0.0001$ & 16.5 & $<0.0001$ & 33.1 & $<0.0001$ \\
\hline & Cycle & 258 & $<0.0001$ & 350 & $<0.0001$ & 129.3 & $<0.0001$ & 846.3 & $<0.0001$ & 38.2 & $<0.0001$ & 34.4 & $<0.0001$ & 40 & $<0.0001$ \\
\hline & Site $\times$ Clone & 12.3 & $<0.01$ & 0.7 & 0.602 & 5.5 & $<0.01$ & 7.3 & $<0.01$ & 8.2 & $<0.01$ & 8.1 & $<0.01$ & 9.9 & $<0.0001$ \\
\hline
\end{tabular}

Tab. 4 - Means and standard errors (in parenthesis) of total shoot height (H) and diameter (D), shoots/stool ratio, and percentage branchiness of hybrid poplar clones after two biennial rotations in the study sites in northern Italy. ( $\S$ ): Shoot diameter measured at $100 \mathrm{~cm}$ above the ground; $(\dagger)$ : number of shoots on the stool; $(\$)$ : percentage allocation ratios between stem and branch woody biomass. Values within each column followed by different letters are statistically different after Duncan's MR Test $(\mathrm{P} \leq 0.05)$. (ns): not significant; $(*)$ : $\mathrm{P} \leq 0.05,(* *)$ : $\mathrm{P} \leq$ $0.01 ;(* * *): \mathrm{P} \leq 0.001$, levels of significance of the differences between the average value of the first and second rotation cycle of each pa rameter in each site.

\begin{tabular}{|c|c|c|c|c|c|c|c|c|c|}
\hline \multirow{2}{*}{ Site } & \multirow{2}{*}{ Clone } & \multicolumn{2}{|c|}{ H (cm) } & \multicolumn{2}{|c|}{$D(\mathbf{c m})^{\S}$} & \multicolumn{2}{|c|}{ Shoots/stool ratio $^{\dagger}$} & \multicolumn{2}{|c|}{ Branchiness (\%) } \\
\hline & & $1^{\text {st }}$ rotation & $2^{\text {nd }}$ rotation & $1^{\text {st }}$ rotation & $2^{\text {nd }}$ rotation & $1^{\text {st }}$ rotation & $2^{\text {nd }}$ rotation & $1^{\text {st }}$ rotation & $2^{\text {nd }}$ rotation \\
\hline \multirow[t]{6}{*}{ Vinovo } & AF2 & $844.5(17.3)^{a}$ & $628.0(10.3)^{a}$ & $6.3(0.3)^{\mathrm{a}}$ & $3.5(0.1)^{\mathrm{a}}$ & $1.2(0.04)^{\mathrm{ns}}$ & $3.9(0.29)^{\mathrm{ns}}$ & $15.5(1.1)^{b}$ & $8.5(1.4)$ \\
\hline & AF6 & $764.2(22.6)^{b c}$ & $587.5(2.7)^{a b}$ & $5.4(0.3)^{b}$ & $3.1(0.03)^{\mathrm{ab}}$ & $1.5(0.06)^{\mathrm{ns}}$ & $4.2(0.24)^{\mathrm{ns}}$ & $16.9(1.3)^{b}$ & 10.6 \\
\hline & Mony & $731.0(11.5)^{\mathrm{c}}$ & $510.7(15.6)^{\mathrm{c}}$ & $5.4(0.2)^{b}$ & $2.9(0.2)^{b}$ & $1.3(0.07)^{\mathrm{ns}}$ & $4.3(0.34)^{\mathrm{ns}}$ & $24.1(1.2)^{\mathrm{a}}$ & 13.2 \\
\hline & 83.1 & 816.5 & $589.7(17.4)^{\mathrm{bc}}$ & $5.2(0.2)^{b}$ & $3.1(0.1)^{b}$ & $1.1(0.03)^{\mathrm{ns}}$ & $4.6(0.31)^{\mathrm{ns}}$ & $19.6(1.5)^{\mathrm{b}}$ & 9.8 \\
\hline & $\mathrm{I}-214$ & $742.5(3.6)^{b c}$ & $559.2(10.5)^{b}$ & $5.5(0.1)^{b}$ & $2.9(0.1)^{b}$ & $1.4(0.1)^{\mathrm{ns}}$ & $4.2(0.41)^{\mathrm{ns}}$ & $17.5(1.8)^{b}$ & 10.9 \\
\hline & mean & 780.0 & 575.0 & $5.6(0.1)^{* * *}$ & 3.1( & $1.3(0.05)^{* * *}$ & $4.2(0.15)^{\mathrm{ns}}$ & $18.7(0.7)^{* * *}$ & $10.6(0.8)$ \\
\hline \multirow[t]{6}{*}{ Bigarello } & $\mathrm{AF} 2$ & $536.5(13.8)^{a}$ & $434.0(9.1)^{c}$ & $4.4(0.2)^{b}$ & $2.4(0.2)^{a}$ & $1.0(-)^{d}$ & $4.1(0.09)^{\mathrm{c}}$ & $20.7(1.3)^{b}$ & $11.3(1.5)^{\mathrm{e}}$ \\
\hline & AF6 & 476.2 & $319.2(1.4)^{d}$ & $3.8(0.1)^{\mathrm{ab}}$ & $2.0(0.1)^{b}$ & $1.3(0.06)^{\mathrm{d}}$ & $4.6(0.33)^{c}$ & $24.0(2.3)^{\mathrm{bc}}$ & $19.3(1.4)^{\mathrm{bcd}}$ \\
\hline & Monviso & $504.8(5.4)^{a b}$ & $259.5(10.1)^{\mathrm{e}}$ & $4.2(0.1)^{\mathrm{a}}$ & $2.1(0.1)^{\mathrm{ab}}$ & $1.2(0.06)^{\mathrm{d}}$ & $5.3(0.3)^{b}$ & $30.2(1.4)^{\mathrm{a}}$ & $14.9(1.6)^{\mathrm{de}}$ \\
\hline & 83.148 .041 & $512.0(7.8)^{\mathrm{ab}}$ & $420.5(17.5)^{\mathrm{c}}$ & $3.8(0.1)^{\mathrm{ab}}$ & $2.0(0.1)^{b}$ & $1.0(0.02)^{\mathrm{d}}$ & $6.1(0.22)^{\mathrm{a}}$ & $31.3(1.7)^{\mathrm{a}}$ & $11.5(1.2)^{\mathrm{e}}$ \\
\hline & $\mathrm{I}-214$ & $425.5(18.1)^{\mathrm{c}}$ & $338.5(11.9)^{d}$ & $3.4(0.3)^{b}$ & $1.8(0.3)^{b}$ & $1.1(0.04)^{d}$ & $4.6(0.25)^{\mathrm{c}}$ & $31.0(1.7)^{\mathrm{a}}$ & $17.3(2.4)^{\mathrm{cd}}$ \\
\hline & mean & $491.0(10.1)^{* * * *}$ & $354.3(15.4)$ & $3.9(0.1)^{* * * *}$ & $2.0(0.1)$ & $1.1(0.03)^{* * *}$ & $4.9(0.18)$ & $27.5(1)^{* * *}$ & $14.7(0.8)$ \\
\hline
\end{tabular}

Tab. 5 - Means and standard errors (in parenthesis) of Nitrogen $(\mathrm{N})$ status in the shoots of hybrid poplar clones after two biennial rotations in the study sites (northern Italy). $(\S)$ : percentage concentration of $\mathrm{N}$ in the above ground woody biomass, including wood and bark; $(\dagger)$ : $\mathrm{N}$ content in the harvestable above ground woody biomass; $(+)$ : Nitrogen Use Efficiency. Values within each column followed by different letters are statistically different after Duncan's MR Test $(\mathrm{P} \leq 0.05) .(*): \mathrm{P} \leq 0.05 ;(* *): \mathrm{P} \leq 0.01 ;(* * *): \mathrm{P} \leq 0.001$, levels of significance of the differences between the average value of the first and second rotation cycle of each parameter in each site.

\begin{tabular}{|c|c|c|c|c|c|c|c|}
\hline \multirow{2}{*}{ Site } & \multirow{2}{*}{ Clone } & \multicolumn{2}{|c|}{$\mathbf{N} \%{ }^{\S}$} & \multicolumn{2}{|c|}{$\mathbf{N}$ uptake $\left(\mathrm{Kg} \mathrm{ha}^{-1}\right)^{\dagger}$} & \multicolumn{2}{|c|}{ NUE * } \\
\hline & & $1^{\text {st }}$ rotation & $2^{\text {nd }}$ rotation & $1^{\text {st }}$ rotation & $2^{\text {nd }}$ rotation & $1^{\text {st }}$ rotation & $2^{\text {nd }}$ rotation \\
\hline \multirow[t]{6}{*}{ Vinovo } & $\mathrm{AF} 2$ & $0.59(0.016)^{f}$ & $0.80(0.003)^{d}$ & $165.7(4.4)^{\mathrm{de}}$ & $210.5(16.1)^{\mathrm{cd}}$ & $168.8(43)^{\mathrm{a}}$ & $125.2(0.4)^{d}$ \\
\hline & AF6 & $0.75(0.013)^{\mathrm{c}}$ & $1.05(0.003)^{b}$ & $225.9(3.7)^{c}$ & $286.0(15.8)^{b}$ & $133.2(2.2)^{b c}$ & $96.3(0.3)^{f}$ \\
\hline & Monviso & $0.96(0.020)^{\mathrm{e}}$ & $0.96(0.060)^{\mathrm{c}}$ & $245.5(5.1)^{\mathrm{bc}}$ & $250.3(16.7)^{b c}$ & $104.2(2.2)^{\mathrm{e}}$ & $103.8(0.6)^{\mathrm{e}}$ \\
\hline & 83.148 .041 & $0.73(0.016)^{\mathrm{e}}$ & $1.15(0.002)^{\mathrm{a}}$ & $164.5(3.6)^{\mathrm{de}}$ & $340.8(18.3)^{\mathrm{a}}$ & $137.8(3.0)^{b}$ & $87.0(0.2)^{\mathrm{g}}$ \\
\hline & $\mathrm{I}-214$ & $0.60(0.003)^{f}$ & $0.78(0.005)^{d}$ & $132.2(0.7)^{\mathrm{e}}$ & $172.2(10.6) \mathrm{de}$ & $165.4(0.9)^{\mathrm{a}}$ & $127.5(0.8)^{\mathrm{cd}}$ \\
\hline & mean & $0.73(0.040)^{* * *}$ & $0.95(0.030)$ & $186.8(11)^{* * * *}$ & $252.0(15)$ & $141.9(6.2)^{* * * *}$ & $108.0(3.6)$ \\
\hline \multirow[t]{6}{*}{ Bigarello } & AF2 & $0.65(0.024)^{f}$ & $0.86(-)^{\text {cd }}$ & $73.1(2.7)^{b c}$ & $129.3(14.9)^{b c}$ & $155.4(5.61)^{\mathrm{a}}$ & $116.6(0.02)^{\mathrm{cd}}$ \\
\hline & AF6 & $0.73(0.036)^{\mathrm{e}}$ & $0.89(0.001)^{\mathrm{bc}}$ & $84.2(4.2)^{\mathrm{b}}$ & $102.6(10.5)^{\mathrm{bc}}$ & $138.0(7.23)^{b}$ & $112.7(0.08)^{\mathrm{cd}}$ \\
\hline & Monviso & $0.91(0.031)^{b c}$ & $0.93(0.015)^{b}$ & $123.1(4.2)^{\mathrm{a}}$ & $175.1(29.8)^{\mathrm{ab}}$ & $110.7(3.91) \mathrm{de}$ & $107.4(1.89)^{\text {de }}$ \\
\hline & 83.148 .041 & $1.00(0.004)^{\mathrm{a}}$ & $1.00(0.019)^{\mathrm{a}}$ & $111.3(0.4)^{\mathrm{a}}$ & $222.6(42.5)^{\mathrm{a}}$ & $100.2(0.41)^{\mathrm{e}}$ & $99.8(2.18)^{\mathrm{e}}$ \\
\hline & $\mathrm{I}-214$ & $0.75(0.002)^{\mathrm{e}}$ & $0.82(0.012)^{a}$ & $54.4(0.8)^{c}$ & $69.8(14.0)^{\mathrm{c}}$ & $133.3(1.85)^{b}$ & $121.9(2.13)^{\mathrm{c}}$ \\
\hline & mean & $0.81(0.030)^{* * *}$ & $0.90(0.020)$ & $89.2(7.4)^{* *}$ & $139.9(16.5)$ & $127.5(5.5)^{* * *}$ & $111.7(1.8)$ \\
\hline
\end{tabular}




\section{Nitrogen use}

Results of the ANOVA carried out on $\mathrm{N}$ use parameters are shown in Tab. 3. At both sites, clone and cycle effects were highly significant for $\mathrm{N} \%$, with a significant increment from the first to the second rotation (Tab. 5). "Monviso" and "83.148.041" clones had the highest values of wood N\% across the two sites after the first cycle. These two clones showed the highest $\mathrm{N} \%$ after the second cycle at Bigarello, while at Vinovo the clone "83.148.041" had the highest N\% value along with clone "AF6". After the first rotation, "Monviso" had the highest $\mathrm{N}$ uptake in both sites. After the second rotation, "83.148.041" had by far the highest $\mathrm{N}$ uptake.

NUE was significantly affected by clone and cycle effects at both sites, with a significant decrease from the first to the second rotation.

\section{Correlations, yield and $N$ uptake}

N\% and NUE were never correlated with the shoot dimensions (Tab. 6), meaning that $\mathrm{D}$ and $\mathrm{H}$ did not affect the $\mathrm{N}$ use parameters of the studied clones. On the contrary, several significant correlation coefficients were found between the branching and sprouting habits and the $\mathrm{N}$ use parameters. Fig. 2 shows the linear regressions between branchiness and wood $\mathrm{N} \%$ at both sites and across the two rotation cycles. The regression coefficients were never significant after the second rotation cycle, when branchiness remarkably decreases as a consequence of the strong increase of shoot density after coppicing. At the end of the first cycle, with higher values of branchiness, the regression coefficient was $\mathrm{R}^{2}=0.813(\mathrm{p} \leq 0.05)$ at $\mathrm{Vi}$ novo and $\mathrm{R}^{2}=0.621(\mathrm{p} \leq 0.10)$ at Bigarello. In both cases, clone "AF2" showed the lowest values of branchiness and the lowest values of wood $\mathrm{N} \%$. In contrast, clones "Monviso" and "83.148.041" showed high values of branchiness and high wood N\%.

Fig. 3 shows the linear regressions between the shoots/stool ratio and wood N\% in the two sites and across the two rotation cycles. The regression was never significant after the first rotation cycle. After the second cycle, with higher values of shoots/stool ratio, the regression coefficient were $\mathrm{R}^{2}=0.804(\mathrm{p}$ $\leq 0.05)$ at Bigarello and $\mathrm{R}^{2}=0.56(\mathrm{p} \leq 0.10)$ at Vinovo. In both cases, the lowest values of shoots/stool ratio and wood N\% were observed for clones "AF2" and "I214". In contrast, "83.148.04"1 had the highest values of shoots/stool ratio and the highest wood N\%.

Yield data as aboveground woody biomass of the studied poplar clones are reported in Tab. 7. N uptake in the aboveground woody biomass of the five clones in relation to the corresponding annual yield across the two study sites and the two rotation cycles are shown in Fig. 4. Data are reported as single

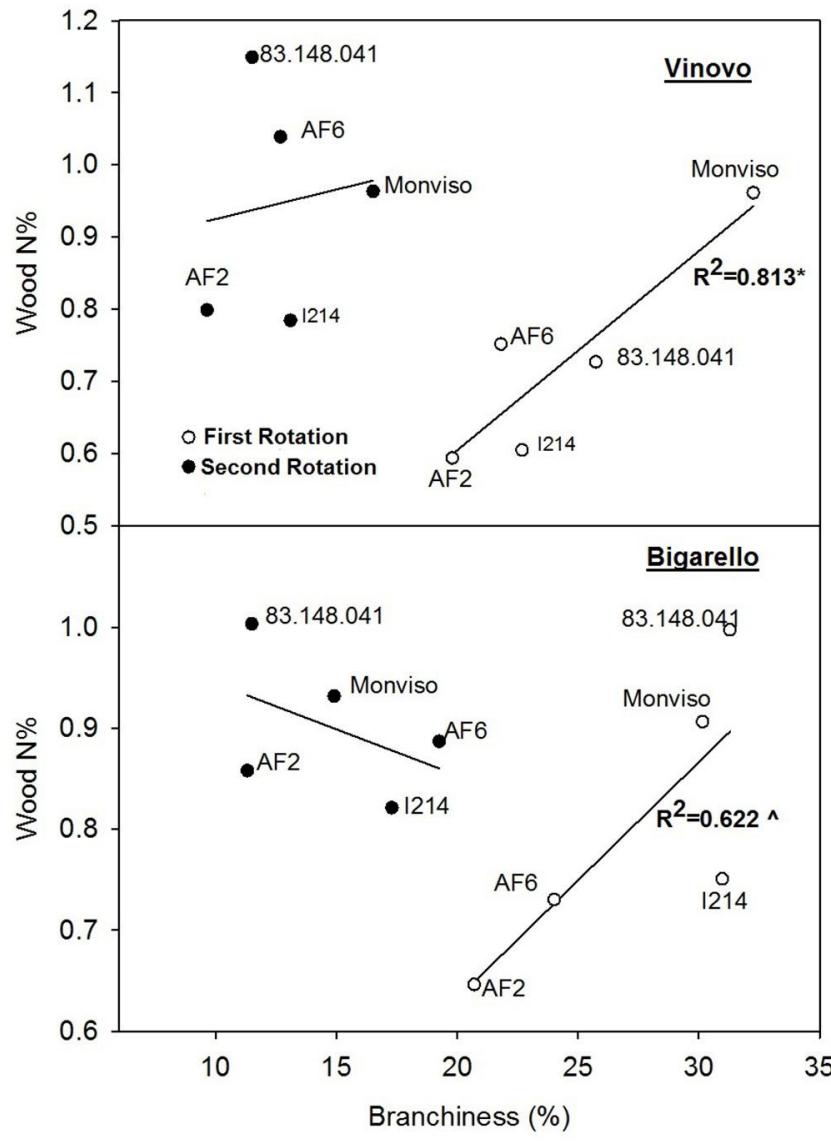

Fig. 2 - Linear regressions between the percentage woody biomass allocated to the branches (branchiness, in \%) as the independent variable, and the percentage $\mathrm{N}$ concentration in the wood (N\%) as the dependent variable, for the five clones in the two study sites (northern Italy), in relation to first and second biennial rotations. Each point represents the mean value of 3 replications. $(*)$ : $\mathrm{P}$ $\leq 0.05 ;\left(^{\wedge}\right): \mathrm{P} \leq 0.1$. See Tab. 2, Tab. 4 and Tab. 5 for additional information.

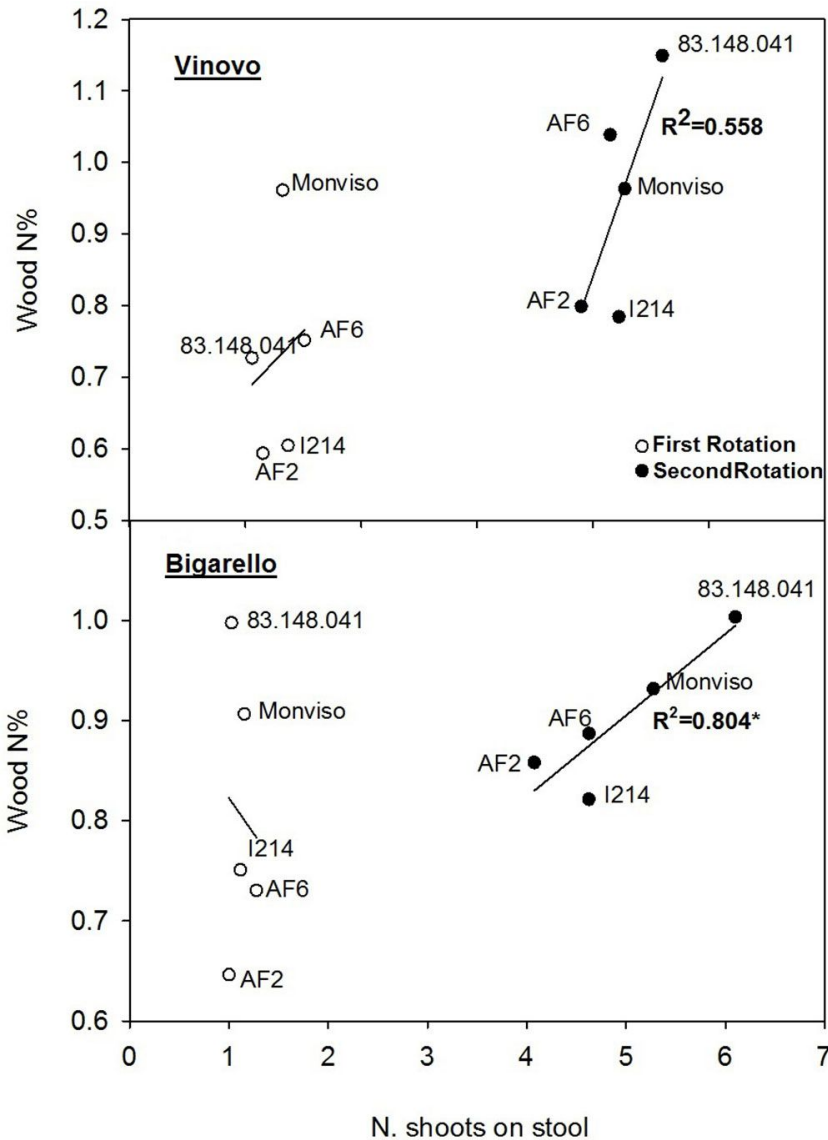

Fig. 3 - Linear regressions between the shoots/stool ratio (the number of shoots on the stool) as the independent variable, and the percentage $\mathrm{N}$ concentration in the wood (N\%), as the dependent variable, for the five clones in the two study sites (northern Italy), in relation to first and second biennial rotations. Each point represents the mean value of 3 replications. $(*): \mathrm{P} \leq 0.05 ;\left(^{\wedge}\right)$ $\mathrm{P} \leq 0.1$. See Tab. 2, Tab. 4 and Tab. 5 for additional information. 
Tab. 6 - Pearson's correlation coefficients $\left(\mathrm{R}^{2}\right)$ between Nitrogen use parameters and morphological yield traits of hybrid poplar clones after two biennial rotations in the study sites (northern Italy). (1): Shoot diameter, measured at $100 \mathrm{~cm}$ above the ground; (2): total shoot height; (3): percentage allocation ratios between stem and branch woody biomass;. (4): number of shoots on the stool; (5): percentage concentration of $\mathrm{N}$ in the above ground woody biomass, including wood and bark; (6): $\mathrm{N}$ content in the harvestable above ground woody biomass; (7): Nitrogen Use Efficiency.

\begin{tabular}{|c|c|c|c|c|c|c|c|c|}
\hline \multirow{3}{*}{ Variable } & \multicolumn{4}{|c|}{ Vinovo } & \multicolumn{4}{|c|}{ Bigarello } \\
\hline & \multicolumn{2}{|c|}{$1^{\text {st }}$ rotation } & \multicolumn{2}{|c|}{$2^{\text {nd }}$ rotation } & \multicolumn{2}{|c|}{$1^{\text {st }}$ rotation } & \multicolumn{2}{|c|}{$2^{\text {nd }}$ rotation } \\
\hline & $\mathbf{N \%}{ }^{6}$ & NUE $^{7}$ & N\% & NUE & $\mathbf{N \%}$ & NUE & N\% & NUE \\
\hline$\overline{D^{1}}$ & 0.298 & 0.385 & -0.055 & 0.065 & 0.040 & -0.076 & 0.004 & 0.001 \\
\hline $\mathrm{H}^{2}$ & -0.299 & 0.271 & -0.006 & 0.018 & 0.014 & 0.0003 & 0.012 & -0.006 \\
\hline Branchiness $(\%)^{3}$ & $0.813^{*}$ & $-0.747 * *$ & 0.017 & -0.039 & 0.622 & $-0.701 * *$ & -0.205 & 0.192 \\
\hline Shoots/stool ratio ${ }^{4}$ & 0.041 & 0.045 & 0.558 & -0.505 & -0.012 & 0.001 & $0.804 *$ & $-0.761^{*}$ \\
\hline Biennial Yield $^{5}$ & 0.014 & -0.018 & $0.708^{\wedge}$ & -0.694 & 0.097 & -0.074 & $0.839 *$ & $-0.844 *$ \\
\hline
\end{tabular}

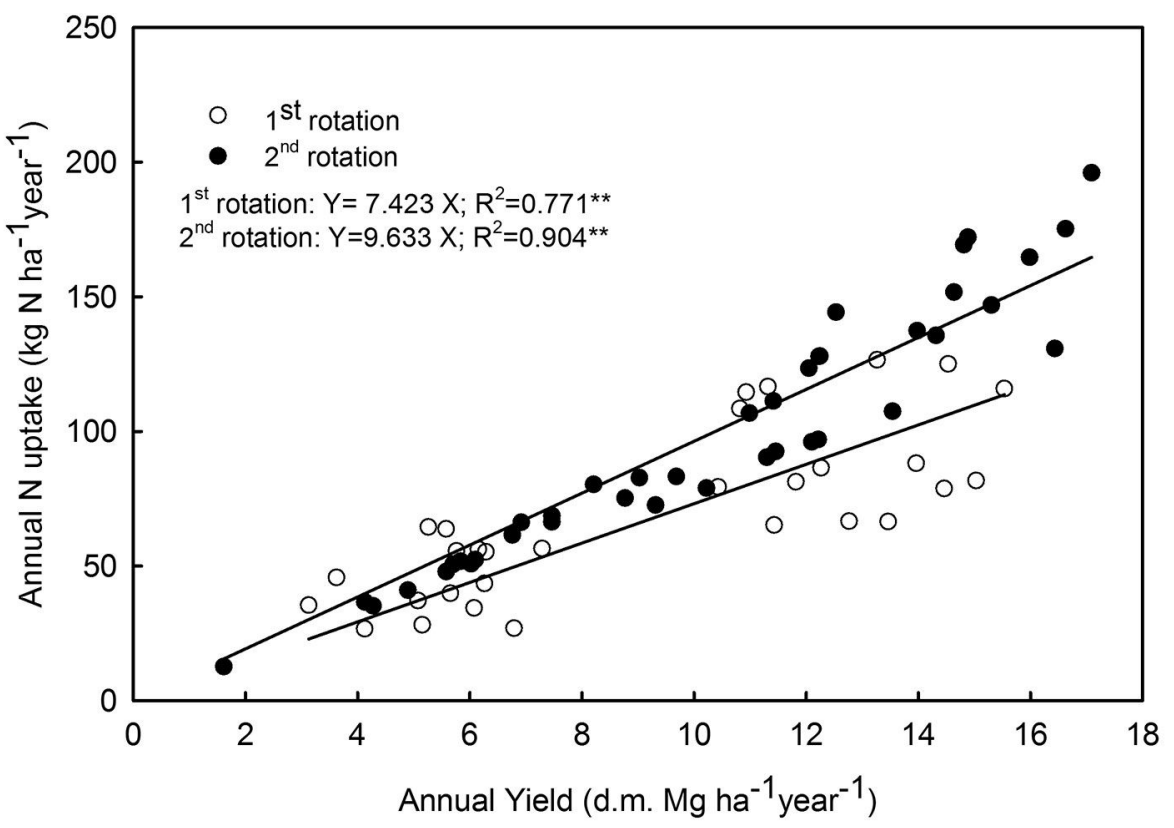

Fig. 4 - Linear regressions between annual yield in dry matter (d.m.) woody biomass as independent variable and Nitrogen $(\mathrm{N})$ uptake in the harvestable biomass as dependent variable for the 5 clones in the two study sites in northern Italy, in relation to first and second biennial rotations. Each point represents a single replication (plot) value. $(* *): \mathrm{P} \leq 0.01$.

Tab. 7 - Means and standard errors (in parenthesis) of dry matter (d.m.) biennial above ground woody biomass yield $\left(\mathrm{Mg} \mathrm{dm} \mathrm{ha} \mathrm{a}^{-1}\right)$ of hybrid poplar clones after two biennial rotations in the study sites in northern Italy. Readapted from Paris et al. (2011). Within each column, values followed by different letters are statistically different according to Duncan's MR Test $(\mathrm{P} \leq 0.05)$. (ns): not significant difference between the yield average values of the first and second rotation cycle in each site.

\begin{tabular}{lllcc}
\hline \multirow{2}{*}{ Clone } & \multicolumn{2}{c}{ Vinovo } & \multicolumn{2}{c}{ Bigarello } \\
\cline { 2 - 5 } & $\mathbf{1}^{\text {st }}$ rotation & $\mathbf{2}^{\text {nd }}$ rotation & $\mathbf{1}^{\text {st }}$ rotation & $\mathbf{2}^{\text {nd }}$ rotation \\
\hline AF2 & $27.93(3.81)^{\mathrm{ab}}$ & $26.37(2.40)^{\mathrm{a}}$ & $11.31(1.78)^{\mathrm{ab}}$ & $15.07(2.01)^{\mathrm{ab}}$ \\
AF6 & $30.07(2.50)^{\mathrm{a}}$ & $27.56(1.86)^{\mathrm{a}}$ & $11.52(1.58)^{\mathrm{ab}}$ & $11.57(1.36)^{\mathrm{ab}}$ \\
Monviso & $25.53(3.26)^{\mathrm{ab}}$ & $26.02(2.13)^{\mathrm{a}}$ & $13.58(1.73)^{\mathrm{a}}$ & $18.62(3.26)^{\mathrm{a}}$ \\
83.148 .041 & $22.64(1.63)^{\mathrm{b}}$ & $29.66(1.86)^{\mathrm{a}}$ & $11.16(0.50)^{\mathrm{ab}}$ & $22.24(8.87)^{\mathrm{a}}$ \\
$\mathrm{I} 214$ & $21.86(1.58)^{\mathrm{b}}$ & $21.93(1.43)^{\mathrm{b}}$ & $7.25(1.69)^{\mathrm{b}}$ & $8.40(1.87)^{\mathrm{b}}$ \\
Mean & $25.60(2.55)^{\mathrm{ns}}$ & $26.31(1.94)$ & $10.96(1.46)^{\mathrm{ns}}$ & $15.18(3.46)$ \\
\hline
\end{tabular}

replication values. These data are well stratified into two different linear regressions for the first and the second rotation cycle.

\section{Discussion}

Nitrogen removal by harvest and its implications for assessing $N$ fertilization in SRCs

Bioenergy plantations of hybrid poplars, under short rotation coppicing (SRC) management are intensive systems of forestry plantation, requiring optimal site conditions in terms of soil quality, nutrient availability and soil moisture balance, as well intensive cultural practices such as weed control, irrigation and fertilization (Heilman \& Norby 1988, Guidi et al. 2009, Pistocchi et al. 2009, Bergante et al. 2010, Sabatti et al. 2014). Consequently, poplar SRC should be considered and managed as a system closer to agriculture than to silviculture. The importance of $\mathrm{N}$ in promoting poplar tree nutrition, growth and biomass yield has often been demonstrated in different site conditions and management options (Czapowskyj \& Safford 1993, Heilman \& Xie 1993, Brown \& van den Driessche 2005, Coyle \& Coleman 2005, Bilodeau-Gauthie et al. 2011). In this study, we obtained high values of $\mathrm{N}$ removal in the woody biomass harvested in the first and second biennial cycles (Fig. 4). Comparison with similar studies in the literature is difficult (Adegbidi et al. 2001, Jug et al. 1999, Tzanakakisa et al. 2009, Tzanakakisa et al. 2009), mainly because $\mathrm{N}$ removal with SRC harvesting is affected by many factors, such as the yield, the rotation cycle, the fertilization and irrigation regime. Indeed, all of the aforementioned authors did not develop a relationship between annual yield and $\mathrm{N}$ removal.

The two plantations considered in this study were established on alluvial arable soils with contrasting soil qualities within a larger network of plantations aimed at testing SRC poplar clones across Italy (Paris et al. 2011, Sabatti et al. 2014. Annual clonal yields ranged between 5-25 dry matter (dm) $\mathrm{Mg} \mathrm{ha}^{-1}$ year $^{-1}$ (Mareschi et al. 2005, Paris et al. 2011). The clones chosen for this study are among the best performing in SRC in Italy, along with the clone "I214" which is the most used for timber plantations across Italy, mainly in the continental northern part. Both the study sites are located in the Po plain, the largest and most fertile agricultural area in northern Italy. Bigarello was the poorest site in the plantation network, with soil texture ( $43.3 \%$ clay) and $\mathrm{pH}(8.34)$ outside of the optimal range for hybrid poplar cultivation in Italy. Contrastingly, Vinovo was an average site in terms of biomass yield and site characteristics. Total soluble $\mathrm{N}$ in the soil of the two study sites is quite similar, and no fertilization was carried out at both 
sites during the study.

Using the data collected in these experiments, we established a relationship between the annual yield of aboveground biomass and $\mathrm{N}$ removal for poplar SRC in Italy (Fig 4). This relationship may be considered a useful tool for assessing the fertilization balance of poplar SRC plantations for nitrogen. However, these data must be used with caution and fertilization needs to be tailored to the specific poplar SRC plantation. Although $\mathrm{N}$ removal by harvest is relevant, it is just one factor affecting $\mathrm{N}$ cycling, which mainly depends on the balance between $\mathrm{N}$ losses (leaching, denitrification and $\mathrm{N}$ uptake in stumps/root biomass) and inputs ( $\mathrm{N}$ from natural depositions, annual leaf fall and fine root mortality - Heilman \& Norby 1988) Generalization is hard to achieve both for $\mathrm{N}$ inputs and outputs, since many of these factors are site- and/or crop-specific.

Three main general observations regarding tailoring $\mathrm{N}$ fertilization in poplar SRC plantations may be highlighted here. Firstly, N uptake values in the aboveground woody biomass of poplar SRCs are comparable to those of many temperate agricultural crops (Maynard \& Hochmuth 2007). Secondly, at the same level of productivity, the need for $\mathrm{N}$ input increases considerably between the first and the second cycle of poplar SRC plantations (Fig. 4). In fact, shoot density increased dramatically during the second cycle due to coppicing, thus reducing shoot dimensions (Tab. 4). This has also been observed by other authors on shoot density and shoot diameter after coppicing, both in hybrid poplar and willow SRC plantations (Adegbidi et al. 2001, Al Afas et al. 2008) The third general observation is that in SRCs coppicing led to a significant shift in shoot population density and dimensions, thus altering the bark and nutrients percentages in the above ground woody biomass, with a concomitant increment in $\mathrm{N} \%$ in the harvest.

\section{Contribution of yield traits and \\ determinants of $N$ removal}

We found an extremely high variability in average annual removal of $\mathrm{N}$ amongst the studied clones (Tab. 5). This clonal variability was determined more by annual yield than $\mathrm{N} \%$. For each clone, the coefficient of variation $(\mathrm{CV} \%)$ for biomass yield was always higher than $28.5 \%$, while the $\mathrm{CV} \%$ for $\mathrm{N} \%$ was never higher than $18.2 \%$ (data not shown). This is in agreement with Adegbidi et al. (2001) who studied biomass yield and nutrient uptake and concentrations on the woody biomass of willow and poplar clones for SRC in the USA. In our study, clone "I214" had the lowest N uptake always and the lowest yield. The clone with the highest $\mathrm{N}$ uptake was "83.148.041", which was also the most productive clone in our experiments. This means that N\% is a secondary parameter as compared with biomass yield in affecting clonal variability in $\mathrm{N}$ uptake amongst the hybrid poplar clones for SRC. $\mathrm{N} \%$ varied between a minimum of $0.59 \%$ for "AF2" in Vinovo during the first rotation to a maximum of $1.15 \%$ for " 83.148 .041 " in Vinovo during the second rotation. These values are extremely high when compared with those reported by other authors who studied N\% in the woody biomass of Salicaceae clones under SRC management. For example, Jug et al. (1999) reported a variation range in $\mathrm{N} \%$ between $0.27-0.69 \%$ for three clones (two poplars and one willow) in Germany under a short rotation management with a 5-year coppicing cycle and biomass yield ranging between ca. 10-14 Mg dm ha ${ }^{-1}$ year $^{-1}$ (Hofmann-Schielle et al. 1999). In this case, the low $\mathrm{N} \%$ in woody biomass may be explained by a rotation cycle longer than that adopted in our study. Moreover, Adegbidi et al. (2001) also investigated nutrient concentrations in the woody biomass of five willow and one hybrid clones in the New York State, with N\% ranging from 0.38 to 0.93 , according to 1-3 year coppicing rotation cycles. Such values were surprisingly lower as compared with our study, mainly considering the shorter rotation cycles and the higher number of sprouts per stool of willow SRCs. However, no detailed information on sampling for chemical analysis were reported therein.

Our study highlighted the importance of productive determinants in Salicaceae clones such as branching and the shoots/stool ratio in affecting $\mathrm{N} \%$ in the woody biomass produced by SRC plantations (Ceulemans et al. 1990, Scarascia-Mugnozza et al. 1997, Zelezink 2007, Dillen et al. 2009). We found significant and positive regression coefficients between Branch\% and N\% during the first rotation cycle at both study sites (Tab. 6). After coppicing (second rotation), N\% became strongly related to the shoots/stool ratios, with an increment in shoot density and a decrease in branch\%. Such evidence can be easily explained by the fact that both branch $\%$ and shoots/stool ratio should increase the bark percentage, thus increasing $\mathrm{N} \%$ in the total woody biomass (Paris et al. 2006).

Two ideotypes of hybrid poplar clones with successful yield performance, but with opposite $\mathrm{N} \%$ have been identified by this study. Clones like "AF2" combined low N\% with low values of branch $\%$ and shoots/stool ratio during the first and second cycles, respectively. In contrast, clones like "Monviso" and "83.148.041" presented high N\% with high values of the aforementioned morphological traits. Ceulemans et al. (1990) and Scarascia-Mugnozza et al. (1997) demonstrated the importance of sylleptic branches in improving growth and yield of hybrid poplar clones. More recently, several pedigree studies showed that successful genotype ideotypes in growth and yield can exhibit opposite morphological characteristics as for branching (Tharakan et al. 2001, 2005, Rae et al. 2004, Dillen et al. 2009) and sprouting habits (Rae et al. 2004). Our experiments showed that high yielding clones, such as "Monviso" and "83.148.041" (Paris et al. 2011, Sabatti et al. 2014), combine high branching and sprouting habit with low NUE. In contrast, "AF2" presents moderate to good yield performance (Paris et al. 2011, Sabatti et al. 2014), low branching and sprouting habits, as well as high NUE.

\section{Conclusions}

Nitrogen balance is a factor of considerable importance for the sustainability of bioenergy crops, in terms of their energy balance, greenhouse gas emission, environmental contamination, and biofuel quality (Chum et al. 2011). Selecting bioenergy crops with a low need of $\mathrm{N}$ fertilization is therefore crucial, as well as a low level of $\mathrm{N}$ content in the harvested and processed biomass. Tailoring $\mathrm{N}$ application to the real need of the crop is also a viable strategy for reducing $\mathrm{N}$ contamination in the environment and $\mathrm{N}$ content in the harvested biomass.

The $\mathrm{N}$ removal by harvesting was studied in two poplar coppice bioenergy plantations during the first two rotation cycles of new hybrid clones, specifically selected for intensive management with high planting density (about 6000 plants $^{-1}$ ) and a very short harvesting cycle ( 2 years). These kinds of agroforestry systems are intensive forms of bioenergy plantations of increasing importance in many countries with temperate climatic conditions (Christersson \& Verma 2006, El Kasmioui \& Ceulemans 2012). The studied clones are currently used at a commercial level in Italy and other European countries.

$\mathrm{N}$ removal was found to be primarily influenced by biomass production. A significant relationship between biomass yield and $\mathrm{N}$ removal was detected. Such relationship can be used to refine $\mathrm{N}$ fertilization balance for the woody crop, both using chemical fertilizers and organic waste for disposal in bioenergy plantations (phytoremediation - Rosenquist \& Dawson 2005, Dimitriou \& Rosenqvist 2011). Coppicing improved the amount of $\mathrm{N}$ removal dramatically, as a consequence of strong changes in the morphological traits and density of shoot populations. Morphological shoot traits were found to be correlated at a clonal level to $\mathrm{N}$ concentration in the woody tissues, as well as to the NUE of the poplar clones. Low branchiness was related to low $\mathrm{N}$ concentration in the harvested wood. A low number of shoots per stool after coppicing was also found to be correlated with low N\% and high NUE. Clone "AF2" had high NUE, low branchiness and a low shoots/stool ratio, combined with moderate 
to good biomass production in the present study. Clone "AF2" is also a productive clone with a stable yield across sites and coppicing cycles, s shown by other experiments in Italy (Minotta \& Muzzi 2007, Fecondo et al. 2010, Di Matteo et al. 2012, Sabatti et al. 2014).

Our results demonstrate the feasibility of cultivar selection in poplars for SRC aimed at improving the NUE of genotypes, along with their biomass yield, the low branchiness and a low number of shoots per stool, as in the case of clone "AF2".

\section{Acknowledgments}

This study was funded by the Consiglio per la Ricerca e la Sperimentazione in Agricoltura, Italy, "BIOENERLEGNO Project 2008-09", and by the European transnational Project "AgroCop: Maximizing Timber and Energy Wood Production by Innovative Agroforestry Systems with Short Rotation Coppice as Intercrop, 2012-14", WoodWisdom-Net - ERA-NET Bioenergy. L. Tosi's $\mathrm{PhD}$ fellowship was funded in equal parts by the project AgroCop and by the University of Tuscia, Viterbo, Italy. The authors acknowledge two anonymous reviewers for their useful comments on the manuscript.

\section{References}

Adegbidi HG, Volk TA, White EH, Abrahamson LP, Briggs RD, Bickelhaupt DH (2001). Biomass and nutrient removal by willow clones in experimental bio-energy plantations in New York State. Biomass and Bioenergy 20 (6): 399411. - doi: 10.1016/S0961-9534(01)00009-5

Adler A, Verwijst T, Aronsonn P (2005). Estimation and relevance of bark proportion in a willow stand. Biomass and Bioenergy 29 (2): 102-113. doi: 10.1016/j.biombioe.2005.04.003

Al Afas N, Marron N, Van Dongen S, Laureysens I, Ceulemans R (2008). Dynamic of biomass production in a poplar coppice culture over three rotations (11 years). Forest Ecology and Management 255 (5-6): 1883-1891. - doi: 10.1016/j. foreco.2007.12.010

Bergante S, Facciotto G, Minotta G (2010). Identification of the main site factors and management intensity affecting the establishment of Short-Rotation-Coppices (SRC) in Northern Italy through stepwise regression analysis. Central European Journal of Biology 5 (4): 522-530. - doi 10.2478/s11535-010-0028-y

Berthelot A, Ranger J, Gelhaye D (2000). Nutrient uptake and immobilization in a short-rotation coppice stand of hybrid poplars in north-west France. Forest Ecology and Management 128 (3): 167-179. - doi: 10.1016/S0378-1127(99)00 145-0

Bilodeau-Gauthie S, Paré D, Messier C, Bélanger N (2011). Juvenile growth of hybrid poplars on acidic boreal soil determined by environmental effects of soil preparation, vegetation control, and fertilization. Forest Ecology and Management 261 (3): 620-629. - doi: 10.1016/j.foreco.
2010.11.016

Blanco-Canqui H (2010). Energy crops and their implications on soil and environment. Agronomy Journal 102 (2): 403. - doi: 10.2134/agronj2009. 0333

Brown KR, van den Driessche R (2005). Effects of nitrogen and phosphorus fertilization on the growth and nutrition of hybrid poplars on Vancouver Island. New Forests 29 (1): 89-104. - doi: 10.1007/s11056-004-5418-4

Ceulemans R, Stettler RF, Hinckley TM, Isebrands JG, Heilman PE (1990). Crown architecture of Populus clones as determined by branch orientation and branch characteristics. Tree Physiology 7 (1-2-3-4): 157-167. - doi: 10.1093/tree phys/7.1-2-3-4.157

Christersson L, Verma K (2006). Short-rotation forestry - a complement to "conventional" forestry. Unasyslva 223: 34-39. [online] URL: http://www.cabdirect.org/abstracts/20063146709 .html

Chum H, Faaij A, Moreira J, Berndes G, Dhamija P, Dong H, Gabrielle B, Eng AG, Lucht W, Mapako M, Cerutti OM, Mcintyre T, Minowa T, Pingoud K, Bain R, Chiang R, Dawe D, Heath G, Junginger M, Patel M, Yang J, Warner E, Paré D, Ribeiro SK (2011). Bioenergy. In: "IPCC Special Report on Renewable Energy Sources and Climate Change Mitigation" (Edenhofer O, Pichs-Madruga R, Sokona Y, Seyboth K, Kadner S, Zwickel T, Eicjmeier P, Hansen G, Schlomer S, Von Stechow C, Matschoss P eds). Cambridge University Press, Cambridge, United Kingdom and New York, NY, USA, pp. 1075 doi: 10.1017/CBO9781139151153

Coyle DR, Coleman MD (2005). Forest production responses to irrigation and fertilization are not explained by shifts in allocation. Forest Ecology and Management 208 (1-3): 137-152. - doi: 10.1016/j.foreco.2004.11.022

Czapowskyj MM, Safford LO (1993). Site preparation, fertilization, and 10-year yields of hybrid poplar on a clearcut forest site in eastern Maine, USA. New Forest 7: 331-344. [online] URL: http://link.springer.com/article/10.1007/BF0003 6753

Di Matteo G, Sperandio G, Verani S (2012). Field performance of poplar for bioenergy in southern Europe after two coppicing rotations: effects of clone and planting density. iForest 5 (5): 224229. - doi: 10.3832/ifor0628-005

Dillen SY, Marron N, Sabatti M, Ceulemans R, Bastien C (2009). Relationship among productivity determinants in two hybrid polar families grown during three years at two contrasting sites. Tree Physiology 29 (8): 975-987. - doi: 10.1093/ treephys/tpp036

Dimitriou I, Rosenqvist H (2011). Sewage sludge and wastewater fertilization of Short Rotation Coppice (SRC) for increased bioenergy production. Biological and economic potential. Biomass and Bioenergy 35 (2): 835-842. - doi: 10.1016/j.biombioe.2010.11.010

Djomo SN, El Kasmioui O, Ceulemans R (2011). Energy and greenhouse gas balance of bioenergy production from poplar and willow: a review.
GCB Bioenergy 3 (3): 181-197. - doi: 10.1111/ j.1757-1707.2010.01073.x

El Kasmioui O, Ceulemans R (2012). Financial analysis of the cultivation of poplar and willow for bioenergy. Biomass and Bioenergy 43: 5264. - doi: 10.1016/j.biombioe.2012.04.006

Erisman JW, Grinsven H, Leip A, Mosier A, Bleeker A (2010). Nitrogen and biofuels; an overview of the current state of knowledge. Nutrient Cycling in Agroecosystems 86 (2): 211223. - doi: 10.1007/s10705-009-9285-4

Fecondo G, Bucciarelli S, Ercole M, Rizzo G (2010). Il pioppo dà più biomassa con turno biennale ed irrigato [Enhanced biomass yield of poplar SRC under 2-year rotation cycle with irrigation]. L'Informatore Agrario 32: 27-29. [in Italian]

Filat M, Chira D, Nica MS, Dogaru M (2010). First year development of poplar clones in biomass short rotation coppiced experimental cultures. Annals of Forest Research 53: 151-160. [online] URL: http://www.afrjournal.org/index. php/afr/article/view/108

Guidi W, Piccioni E, Ginanni M, Bonari E (2009). Bark content estimation in poplar (Populus deltoides) short-rotation coppice in Central Italy. Biomass and Bioenergy 32 (6): 518-524. doi: 10.1016/j.biombioe.2007.11.012

Hansen EA, McLoughlin RA, Pope PE (1988). Biomass and nitrogen dynamics of hybrid poplars on two different soils: implications for fertilization strategy. Canadian Journal of Forest Research 18 (2): 223-230. - doi: 10.1139/x88-033

Heilman P, Norby RJ (1988). Nutrient cycling and fertility management in temperate short rotation forest systems. Biomass and Bioenergy 14 (4): 361-370. - doi: 10.1016/S0961-9534(97)100721

Heilman PE, Stettler RF (1986). Nutritional concerns in selection of black cottonwood and hybrid clones for short rotation. Canadian Journal of Forest Research 16 (4): 860-863. - doi: 10.1139/x86-151

Heilman PE, Xie F (1993). Influence of nitrogen on growth and productivity of short-rotation Populus trichocarpa $\mathrm{x}$ Populus deltoides hybrids. Canadian Journal of Forest Research 23 (9): 1863-1869. - doi: 10.1139/x93-236 Heller MC, Keoleian GA, Volk TA (2003). Life cycle assessment of a willow bioenergy cropping system. Biomass and Bioenergy 25 (2): 147-165. - doi: 10.1016/S0961-9534(02)00190-3

Hofmann-Schielle C, Jug A, Makeschin F, Rehfuess KE (1999). Short-rotation plantations of balsam poplars, aspen and willows on former arable land in the Federal Republic of Germany. II. Site-growth relationships. Forest Ecology and Management 121 (1-2): 41-55. - doi: 10.1016/ S0378-1127(98)00555-6

Jug A, Hofmann-Schielle C, Makeschin F, Rehfuess KE (1999). Short-rotation plantations of balsam poplars, aspen and willows on former arable land in the Federal Republic of Germany. II. Nutritional status and bioelement export by harvested shoot axes. Forest Ecology and Management 121 (1-2): 67-83. - doi: 10.1016/S0378- 
1127(98)00557-X

Kaltschmitt M, Reinhardt GA (1997). Nachwachsende Energietrager - Grundlagen, Verfahren, Ökologische Bilanzierung [Biofuels: Basics, processes, ecological balances]. Vieweg, Braunschweig, Wiesbaden, Germany, pp. 527. [in German]

Klasnja B, Kopitovic S, Orlovic S (2002). Wood and bark of some poplar and willow clones as fuelwood. Biomass and Bioenergy 23 (6): 427432. - doi: 10.1016/S0961-9534(02)00069-7

Kottek MJ, Grieser C, Beck B, Rudolf C, Rubel F (2006). World Map of the Köppen-Geiger climate classification updated. Meteorologische Zeitschrift 15 (3): 259-263. - doi: 10.1127/09412948/2006/0130

Lars R (2002). Nutrient content in stems of hybrid aspen as affected by tree age and tree size, and nutrient removal with harvest. Biomass and Bioenergy 23 (1): 13-25. - doi: 10.1016/S09619534(02)00029-6

Laureysens I, Blust R, De Temmerman L, Lemmens C, Ceulemans R (2004). Clonal variation in heavy metal accumulation and biomass production in a poplar coppice culture. I. Seasonal variation in leaf, wood and bark concentrations. Environmental Pollution 131 (3): 485-494. - doi: 10.1016/j.envpol.2004.02.009

Manzone M, Airoldi G, Balsari P (2009). Energetic and economic evaluation of a poplar cultivation for the biomass production in Italy. Biomass and Bioenergy 33 (9): 1258-1264. - doi: 10.1016/j.biombioe.2009.05.024

Mareschi L, Paris P, Sabatti M, Nardin F, Giovanardi R, Manazzone S, Scarascia Mugnozza G (2005). Le nuove varietà di pioppo da biomassa garantiscono produttività interessanti [The new poplar varieties for bioenergy guarantee attractive productivity]. L'Informatore Agrario 18: 4953. [in Italian]

Maynard DN, Hochmuth GJ (2007). Knott's handbook for vegetable growers $\left(5^{\text {th }}\right.$ edn). John Wiley and Sons, Hoboken, NJ, USA, pp. 621. doi: 10.1002/9780470121474

Minotta G, Muzzi E (2007). Indagini su cedui di pioppo a turno breve nella pianura ferrarese [Researches on Short Rotation Forestry with poplar in the South-Eastern part of the Po Valley (Ita- ly)]. L'Italia Forestale e Montana 5/6: 411-419. [in Italian]

Paris P, Mareschi L, Sabatti M, Breccia L, De Luca S, Tarchi M, Ecosse A, Scarascia Mugnozza G (2006). Asportazioni di azoto con la raccolta di biomassa [Removal of Nitrogen with biomass harvesting in poplar SRC plantations]. Linea Ecologica 4: 2-8. [in Italian]

Paris P, Mareschi L, Ecosse A, Pisanelli A, Sabatti M, Scarascia Mugnozza G (2011). Comparing hybrid Populus clones for SRF across northern italy after two biennial rotations: survival, growth and yield. Biomass and Bioenergy 35 (4): 1524-1532. - doi: 10.1016/j.biombioe.20 10.12.050

Pistocchi C, Guidi W, Piccioni E, Bonari E (2009). Water requirements of poplar and willow vegetation filters grown in lysimeter under Mediterranean conditions: Results of the second rotation. Desalination 246 (1-3): 137-146. - doi: 10.1016/j.desal.2008.03.047

Rae AM, Robinson KM, Street NR, Taylor G (2004). Morphological and physiological traits influencing biomass productivity in short-rotation coppice poplar. Canadian Journal of Forest Research 34 (7): 1488-1498. - doi: 10.1139/x04033

Rosenquist H, Dawson M (2005). Economics of using wastewater irrigation of willow in Northern Ireland. Biomass and Bioenergy 29 (2): 8392. - doi: 10.1016/j.biombioe.2005.04.001

Sabatti M, Fabbrini F, Harfouche A, Beritognolo I, Mareschi L, Carlini M, Paris P, ScarasciaMugnozza G (2014). Evaluation of biomass production potential and heating value of hybrid poplar genotypes in a short-rotation culture in Italy. Industrial Crops and Products 61: 62-73. doi: 10.1016/j.indcrop.2014.06.043

Safou-Matondo R, Deleporte P, Laclau J, Bouillet J (2005). Hybrid and clonal variability of nutrient content and nutrient use efficiency in Eucalyptus stands in Congo. Forest Ecology and Management 210 (1-3): 193-204. - doi: 10.1016/j.foreco.2005.02.049

Scarascia-Mugnozza GE, Ceulemans R, Heilman PE, Isebrands JG, Stettler RF, Hinckley TM (1997). Production physiology and morphology of Populus species and their hybrids grown un- der short rotation. II. Biomass components and harvest index of hybrid and parental species clones. Canadian Journal of Forest Research 27 (3): 285-294. - doi: 10.1139/x96-180

Scharlemann JPW, Laurance WF (2008). How green are biofuels? Science 319 (5859): 43-44. doi: $10.1126 /$ science. 1153103

Scholz V, Ellerbrock R (2002). The growth productivity, and environmental impact of the cultivation of energy crops on sandy soil in Germany. Biomass and Bioenergy 23 (2): 81-92. - doi: 10.1016/S0961-9534(02)00036-3

Sixto H, Salvia J, Barrio M, Ciria MP, Cañellas X (2010). Genetic variation and genotype-environment interactions in short rotation Populus plantations in southern Europe. New Forests 42 (2): 163-177. - doi: 10.1007/s11056-010-9244-6

Tharakan PJ, Robinson DJ, Abrahamson CA, Nowak CA (2001). Multivariate approach for integrated evaluation of clonal biomass production potential. Biomass and Bioenergy 21 (4): 237247. - doi: 10.1016/S0961-9534(01)00038-1

Tharakan PJ, Volk TA, Nowak CA, Abrahamson CA (2005). Morphological traits of 3 willow clones and their relationship to biomass production. Canadian Journal of Forest Research 35 (2): 421-431. - doi: 10.1139/x04-195

Tzanakakisa VA, Paranychianakisb NV, Angelakis AN (2009). Nutrient removal and biomass production in land treatment systems receiving domestic effluent. Ecological Engineering 35 (10): 1485-1492. - doi: 10.1016/j.ecoleng.2009. 06.009

Van Miegroet H, Norby RJ, Tschaplinski TJ (1994). Nitrogen fertilization strategies in a short-rotation sycamore plantation. Forest Ecology and Management 64 (1): 13-24. - doi: 10.101 6/0378-1127(94)90123-6

Vitousek PM (1982). Nutrient cycling and nutrient use efficiency. The American Naturalist 119 (4): 553. [online] URL: http://www.jstor.org/stable/2461143

Zelezink JD (2007). Effects of apical meristem loss on sylleptic branching and growth of hybrid poplar. Biomass and Bioenergy 31 (7): 453-459. - doi: 10.1016/j.biombioe.2007.01.024 